\title{
Parasitic Infections of the Appendix as a Cause of Appendectomy in Adult Patients
}

\author{
Erişkin Hastalarda Apandektomiye Neden Olan Apendiksin Parazit İnfeksiyonları
}

\author{
Hakan Yabanoğlu1 , Hüseyin Özgür Aytaç, Emin Türk1, Erdal Karagülle1, Kenan Çalışkan, \\ Sedat Belli', Fazilet Kayaselçuk², Mehmet Akın Tarım¹
}

1Department of General Surgery, Başkent University Faculty of Medicine, Ankara, Turkey

2Department of Pathology, Başkent University Faculty of Medicine, Ankara, Turkey

\begin{abstract}
Objective: Assessment of frequency and clinical findings of parasitic infections for etiology of acute appendicitis.

Methods: Data of 1452 patients who were carried out appendectomy between January 1999 and December 2012 were analyzed retrospectively. Appendectomy was performed in 1159 of the patients with a pre diagnosis of acute appendicitis. Demographics, physical findings, radiologic and laboratory studies, operative findings, pathological results, presence and type of parasitosis were investigated.

Results: Among the 1159 patients done appendectomy with a pre diagnosis of acute appendicitis, 719 (62\%) were males and 440 (38\%) were females. Parasitic infection was demonstrated in 17 (1.4\%) of them. Mean average age of these patients was $36.6 \pm 20.1$ years. Enterobius vermicularis was present in $15(88.2 \%)$ and Entamoeba histolytica in $2(11.8 \%)$ of the patients. Of the pathology specimens of appendix consisting Enterobius vermicularis, 12 (80\%) were normal appendix tissues, 1 (6.6\%) was acute uncomplicated appendicitis and 2 (13.3\%) were perforated appendicitis. One (50\%) of the two specimens consisting Entamoeba histolytica was normal appendix and the other (50\%) was acute appendicitis.
\end{abstract}

Conclusion: Differential diagnosis of parasitic infections in etiology of acute appendicitis should be made properly. It must be remembered that this attention can save patients from a negative laparotomy and morbidity and mortality of it. (Turkiye Parazitol Derg 2014; 38: 12-6)

Key Words: Acute appendicitis, Intestinal parasitic infection, Enterobius vermicularis, Entamoeba histolytica

Received: 12.06.2013

Accepted: 25.12 .2013

ÖZET

Amaç: Akut apandisitin etyolojisinde parazitik infeksiyonların klinik bulgularının ve sıklığının değerlendirilmesi.

Yöntemler: Ocak 1999 ile aralık 2012 tarihleri arasında apandektomi yapılmış olan 1452 hastanın verileri retrospektif olarak analiz edildi. Bu hastalardan 1159'u akut apandisit ön tanısıyla ameliyat edilmişti. Hastaların demografik özellikleri, fizik muayene bulguları, radyoloji ve laboratuvar sonuçları, ameliyat bulguları, patoloji sonuçları ve parazitlerin varlığı ile tipi araştııldı.

Bulgular: Akut apandisit ön tanısı ile apandektomi yapılan 1159 hastanın 719'u erkek (\%62), 440'ı kadındı (\%38). Bu hastaların 17'sinde (\%1,4)

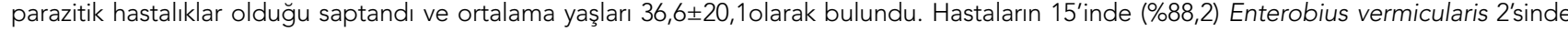
$(\% 11,8)$ Entamoeba histolytica saptandı. Enterobius vermicularis içeren apendiks örneklerinin 12'sinde (\%80) normal apendiks dokusu, 1'inde $(\% 6,6)$ komplike olmayan apandisit ve 2'sinde $(\% 13,3)$ perfore apandisit saptandı. Entamoeba histolytica içeren iki örnekten birinde $(\% 50)$ normal apendiks dokusu diğerinde (\%50) akut apandisit bulundu.

Sonuç: Akut apandisit etyolojisinde parazit infeksiyonlarının ayıııc tanısının doğru yapılmasının önemli olabileceği düşüncesindeyiz. Bu duruma dikkat edilirse negatif laparotomi ve buna bağlı morbidite ve mortalitenin önlenebileceği akılda tutulmalıdır. (Turkiye Parazitol Derg 2014; 38: 12-6)

Anahtar Sözcükler: Akut apandisit, intestinal parazit infeksiyonu, Enterobius vermicularis, Entamoeba histolytica

Geliş Tarihi: 12.06.2013

Kabul Tarihi: 25.12.2013

Address for Correspondence / Yazışma Adresi: Erdal Karagülle, Department of General Surgery, Faculty of Medicine, Başkent University, Ankara, Turkey. Phone: +90 3322570606 E-mail: erenka2000@hotmail.com DOI:10.5152/tpd.2014.3217

CCopyright 2014 Turkish Society for Parasitology - Available online at www.tparazitolderg.org

CTelif hakkı 2014 Türkiye Parazitoloji Derneği - Makale metnine www.tparazitolderg.org web sayfasından ulaşılabilir. 


\section{INTRODUCTION}

Acute appendicitis is a common cause of emergent abdominal surgical procedures (1). Prevalence of appendicitis through whole life is about 6-7\%, with a peak at the 2 nd and 3rd decades (1-3). Appendicitis is more common in developed countries in some degree. The reason for this is the dominance of refined and low fiber consisting aliments in diet (4). Reasons of appendicitis are believed to be multifactorial (5). Most common causes of appendicitis are fecal stasis, fecaliths and lymphoid hyperplasia, whereas unusual reasons are intestinal parasites, tumors, barium used for radiologic studies, vegetable matters and fruit seeds $(2-4,6,7)$. Parasitic infections stand for rare causes of appendicitis. Parasitic and protozoal infections influence more than half of the world's population foremost tropical and developing countries (8). Appendix may sometimes be influenced by parasites. This situation can differ between an innocent reaction and an inflammatory response threatening life. However, the role of parasitic infections in pathogenesis of acute appendicitis is not known exactly (8-12). Most prominent parasitic agents reported to be related with appendicitis are Enterobius vermicularis, Schistosoma spp, Taenia spp, Ascaris lumbricoides (1315). Aim of this study was to determine the role of parasitic infections in acute appendicitis and to detect the incidence of parasitic diseases in appendectomy specimens.

\section{METHODS}

Data of 1452 patients on whom appendectomy had been performed between January 1999 and December 2012 were analyzed retrospectively. Appendectomy procedure had been done with a pre-diagnosis of acute appendicitis to 1159 of the patients and during other surgical interventions (gynecological cancer, laparotomies intending to acute abdomen, colon carcinoma, mesenteric ischemia, Amyand's hernia, etc.) to 293 of the patients. Demographic data, physical findings, radiological and laboratory results, operative findings, pathologic examinations, existence and type of parasites in specimens were evaluated. All specimens were fixed in $10 \%$ formalin and cut into one longitudinal and two transverse samples (3 blocks). Sections were stained with hematoxylin and eosin, and then examined under a light microscope. The 1159 pathology reports were reviewed retrospectively, and cases were classified according to inflammatory changes and existence of parasitic infections. This study was approved by Baskent University Institutional Review Board (Project no: KA13/120, date: 08/05/2013) and supported by Baskent University Research Fund.

\section{Statistical analysis}

Statistical analyses were performed with Statistical Package for the Social Sciences software (Version 9.0; SPSS, Inc., Chicago, IL). Numeric values are expressed as mean \pm standard deviation.

\section{RESULTS}

Among 1159 patients who were operated with a pre-diagnosis of acute appendicitis, 719 (62\%) were male, and 440 (37.9\%) were female. Inflammatory changes due to acute appendicitis in 927 (79.9\%) patients and normal findings in 232 (20\%) patients were prevalent histologically. Parasitic infections were seen in 17 (1.4\%) patients. Of these 17 patients, 11 (64.7\%) were male and 6
(35.3\%) were female. Mean age of the patients was 36.6 20.1 years, ranging from 18 to 73 years. E. vermicularis was determined in 15 (88.2\%) and E. histolytica in 2 (88.2\%) patients. Within appendix specimens containing E. vermicularis (Figure 1), 12 (80\%) exhibited normal appendix tissue, one (6.6\%) acute non-complicated appendicitis and 2 (13.3\%) perforated appendicitis. Moreover, of the specimens containing $E$. histolytica, one (50\%) was concordant with normal appendix tissue and the other (50\%) with acute appendicitis.

Seventeen patients on whom parasitic infections had been demonstrated were admitted to hospital with a lower right abdominal pain. Physically lower right abdominal tenderness and direct - indirect rebound signs were present for all the patients. None of the patients had recent diarrhea history. Leukocyte counts for patients bearing $E$. histolytica and E. vermicularis on whom acute appendicitis had been observed were $16800 / \mathrm{mL}$ and $18400 / \mathrm{mL}$ respectively. For two patients with $E$. vermicularis that were determined to have perforated appendicitis, leukocyte counts were $23800 / \mathrm{mL}$ and $22000 / \mathrm{mL}$ seriatim. Three of the 17 patients had normal leukocyte count rates. Among the patients who were determined to have parasitic infections, acute appendicitis was estimated preoperatively with ultrasound in five and with abdominal tomography scan in two patients. The Alvarado scores of the patients who were analyzed with abdominal tomography scans were 5 and 6 respectively. No further radiological studies were needed for the rest of the patients as their Alvarado scores were higher than 6 within the pathological specimens of these seven patients who were analyzed radiologically, two perforated appendicitis, one acute appendicitis and four normal appendix tissues were observed. No complications were seen during and after operations. All the patients were discharged without any complaint. Same organisms were shown in perianal parasite ova and frozen stool microscopic analyses of all the patients having parasitic infections. All patients were prescribed anti-parasitic medications after their operations.

\section{DISCUSSION}

Intestinal parasitic infections are common in our districts. Clinical reflections of this issue occupy a broad spectrum. Most important of this is acute appendicitis which is one of the major rea-

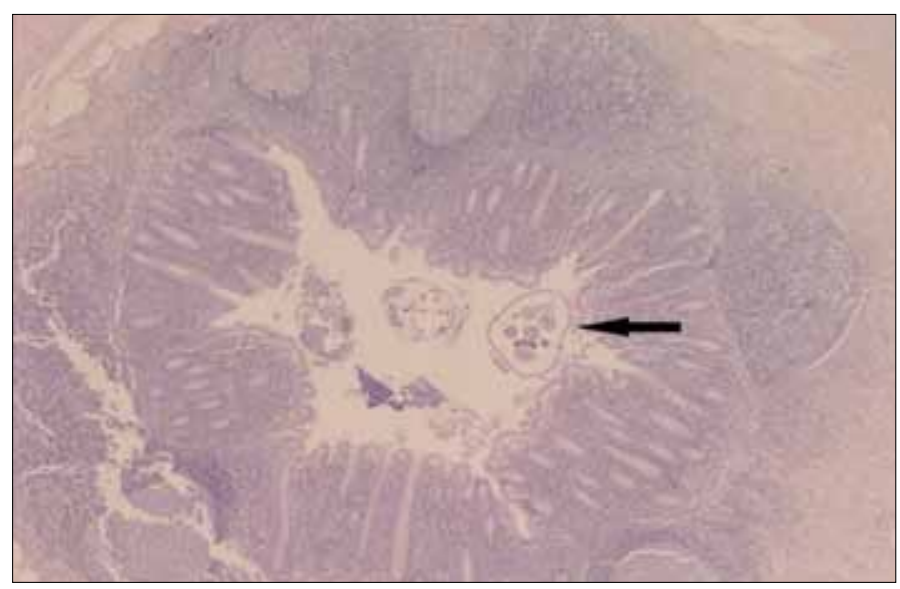

Figure 1. Enterobius vermicularis image within the lumen of the appendix (black arrow), (40xHematoxylin\&Eosin) 
sons of acute abdomen. Parasitic diseases generally account for a rare frequency $(0.05-3 \%)$ for the etiology of appendicitis differing regionally $(5,8,15,16)$. After Fabrius first described parasitic infection of appendix in 1634, Aschoff and friends declared in early 1900's that, lumen of the appendix contains parasites in less than $1 \%$ and this may yield to an infection mimicking symptoms of acute appendicitis or causing appendiceal colic. Role of parasitic infection as a co-factor in appendicitis is controversial even though today. There are only a few evidence about the relation between acute appendicitis and parasites (17-19). Onset of pathogenesis of acute appendicitis may be due to either inflammation occurring secondary to existence of parasites and their ova, or obstruction of the lumen by parasite itself (17-19). Intestinal parasites even though being a rare cause of acute appendicitis, may appear with symptoms and signs similar to acute appendicitis. This situation explains the majority of normal histology in appendectomy specimens. The low incidence of parasites in appendectomy specimens and high ratio of negative appendectomies support the hypothesis that parasitic diseases do not cause appendicitis (5). In our study, the ratio of histopathologic inflammation determination was $79.9 \%$ for appendectomy specimens and $23.5 \%$ for cases with parasitic infections. At this point the dilemma is, whether the existence of parasite in appendix is incidental or a factor of inflammation initiation. Pathogenetic differences between these two situations seem to be unexplainable. Although most of the intestinal parasites are asymptomatic, they may sometimes present with life threatening complications. Through wide spectrum of complications, parasites may cause primary or secondary inflammation for appendix, a such narrower lumen than entire intestine. Whatever the trigger of the mechanism is, we believe that most important point is to illuminate differential diagnosis and treatment strategies for future cases with the results obtained.

Parasitic diseases thought to influence about four billion of people whole through the world especially affecting communities that have lower hygiene and sanitation, socio-economical status, education and living conditions (20). Differences of these risk factors in between districts influence the incidence of intestinal parasitosis. Intestinal parasites cause gastrointestinal diseases and consequent mortalities in tropical geographies. Illnesses accomplished by parasites still protect their importance in Türkiye, a developing country (21). While incidence of $E$. vermicularis in our country was reported as between $8.7 \%$ and $43.3 \%$ in different studies $(20,22,23), 200$ millions of people are thought to be effected from this wide spread disease in the world (15). Although incidence of $E$. histolytica in the world is about $10 \%$, regions where this incidence rises to $50 \%$ to $80 \%$ have been reported. Incidence of $E$. histolytica in Türkiye was reported as $0 \%-17 \%(24,25)$. Parallel to their considerable frequency in population, existence of this two parasites in intestinal system and appendix specimens is inevitable, as in our study.

E. vermicularis is the most prevalent helminthic infectious agent of the gastrointestinal tract whole through the world (8). Relationship between E. vermicularis and appendicitis was first described by Dr. G.F. Still in the late nineteenth century (26). Generally being asymptomatic, its most common presentation is pruritus ani. On the other hand it may present with more serious clinics like ileocolitis, enterocutaneous fistulas, urinary infections, mesenteric abscesses, salpingitis and appendicitis. E. vermicularis is generally sited in terminal ileum, proximal ascending colon, caecum and appendix. It is the major parasite of appendix. Frequency of obtaining E. vermicularis from appendectomy specimens was reported to vary between $0.6 \%-3.8 \%$ in different studies $(8,13,14,27-30)$. The rates observed in our study $(1.29 \%$ for general patient population, $88.2 \%$ for parasitic disease group) is similar with literature. Presence of parasite in appendix lumen can cause many different pathologic conditions varying from phlegmonous inflammation to lymphoid hyperplasia and life threatening peritonitis or gangrenous states (8). In the two patients in whom we observed perforation, disseminated gangrenous changes of appendicitis and peritonitis was present.

Inflammation rate observed in appendix specimens infected by E. vermicularis in literature varies from $13 \%$ to $37 \%(10-12)$. Similarly we observed inflammation concordant with acute and perforated appendicitis in $20 \%$ of our cases. For the patients whose specimens were found to contain E. vermicularis, appendectomy is not the adequate treatment alone. Because surgery does not intend to abolish the cause but only result a condition. Patients must be prescribed anthelmintic medications (oral metronidazole/pyrantel pamoate) after surgery.

Appendicitis related to $E$. histolytica presence is quite rare and generally involve in literature as case reports (18, 31-35). Exact incidence of this atypical presentation of parasitic disease is not well known (36). This rate changes between 0.5-2.3\% among limited number of studies in literature $(14,18,37)$. It was found as $0.17 \%$ in our series. In between patients in those $E$. histolytica was determined, no other organ involvement like liver or colon was seen. Appendectomy is also only a result in this patient group as same as E. vermicularis. That is why appropriate medication (oral metronidazole) should be initiated to prevent from systematic effects of the disease. All of our patients were started medical treatment for parasitic infection after surgery.

Before operation, routine laboratory tests are generally not useful in diagnosis of E. histolytica and E. vermicularis. However, leukocytosis, anemia and elevation of liver enzymes may be seen. No matter how far the clinic, radiological and hematological evaluations are done, elimination of appendicitis in differential diagnosis of this patient cluster cannot be possible all the time. Normal appendix tissue may sometimes be observed although acute appendicitis was suspected in patients due to preoperative laboratory and radiological tests. In our study, in only 4 (57\%) of 7 patients who had radiologically inflammated appendix findings, acute or perforated appendicitis was demonstrated. Similarly, 14 (82\%) of the 17 patients had leukocytosis, but only 4 (23\%) of them showed acute or perforated appendicitis in histopathology.

Hematoxylin and eosin staining is the only parasite searching method in our study. This is the major cons of this study. Therefore this study can be accepted as a study with a fair opinion.

\section{CONCLUSION}

Patients having suspicious clinical findings beside acute abdomen symptoms should be questioned for complaints related to 
parasitic diseases (loss of appetite, diarrhea, paleness, weakness, ova and blood in stool, bloody oral saliva, pruritus ani), vacation history to endemic place, repetitive abdominal pain, previous parasitic disease history and presence of diarrhea. It should be remembered that, parasitic diseases involved in etiology of acute appendicitis may cause similar clinic states without inflammation. Hence proper diagnostic and treatment protocols should be applied. Serologic studies and stool examinations must be done for suspicious cases. Stool examinations is a test very simple and easy to apply in laboratories. Patients who rather have preoperative lower Alvarado scores and/or computed tomography scans not suggesting acute appendicitis should be examined for parasitic infections. Patients determined to have parasitic infections must be followed up after initiation of empirical anthelmintic medication. It must be remembered that, this care can rescue patients from negative laparotomies and related morbidity and mortalities.

Ethics Committee Approval: Ethics Committee Approval: Ethics committee approval was received for this study from the ethics committee of Baskent University (Date: 08/05/2013, Document no: KA13/120).

Informed Consent: Written informed consent was not obtained due to the retrospective nature of the study.

Peer-review: Externally peer-reviewed.

Author Contributions: Concept - H.Y., K.Ç.; Design - H.Y., H.Ö.A.; Supervision - M.A.T.; Funding - H.Y., S.B.; Materials H.Y., H.Ö.A., E.T.; Data Collection and/or Processing - H.Y., K.Ç., F.K.; Analysis and/or Interpretation - H.Y., K.Ç., E.K., E.T.; Literature Review - H.Y., K.Ç., F.K.; Writing - H.Y.; Critical Review - M.A.T., K.Ç., E.K.

Conflict of Interest: No conflict of interest was declared by the authors.

Financial Disclosure: This work was supported by Baskent University Research Fund.

Etik Komite Onayı: Bu çalışma için etik komite onayı Başkent Üniversitesi'nden alınmıştır (Tarih: 08/05/2013, Belge no: KA13/120).

Hasta Onamı: Çalışmanın retrospektif tasarımından dolayı hasta onamı alınmamıştır.

Hakem değerlendirmesi: Dış bağımsız.

Yazar Katkıları: Fikir - H.Y., K.Ç.; Tasarım - H.Y., H.Ö.A.; Denetleme - M.A.T.; Kaynaklar - H.Y., S.B.; Malzemeler - H.Y., H.Ö.A., E.T.; Veri toplanması ve/veya işlemesi - H.Y., K.Ç, F.K.; Analiz ve/veya yorum - H.Y., K.Ç., E.K., E.T.; Literatür taraması H.Y., K.Ç., F.K.; Yazıyı yazan - H.Y.; Eleştirel Inceleme - M.A.T., K.Ç., E.K.

Çıkar Çatışması: Yazarlar çıkar çatışması bildirmemiş̧lerdir.

Finansal Destek: Bu çalışma Başkent Üniversitesi Araştırma Fonu tarafından desteklenmiştir.

\section{REFERENCES}

1. Humes DJ, Simpson J. Acute appendicitis. BMJ 2006; 333: 530-4. [CrossRef]

2. Singh I, Collins RE. Right iliac fossa pain. Br J Hosp Med 2005; 66: 76-8.

3. Flasar MH, Goldberg E. Acute abdominal pain. Med Clin North Am 2006; 90: 481-503. [CrossRef]

4. Kelly AOJ. The pathogenesis of appendicitis. Phil Med J 1899; 21 : 119-37.

5. Karatepe $O$, Adas G, Tukenmez M, Battal M, Altiok M, Karahan S. Parasitic infestation as cause of acute appendicitis. G Chir 2009; 30: 426-8.

6. Nordback I, Harju E. Inflammation parameters in the diagnosis of acute appendicitis. Acta Chir Scand 1988; 154: 43-8.

7. Prystowsky JB, Pugh CM, Nagle AP. Current problems in surgery. Appendicitis. Curr Probl Surg 2005; 42: 688-742. [CrossRef]

8. Da Silva DF, da Silva RJ, da Silva MG, Sartorelli AC, Rodrigues MA. Parasitic infection of the appendix as a cause of acute appendicitis. Parasitol Res 2007; 102: 99-102. [CrossRef]

9. Mogensen K, Pahle E, Kowalski K. Enterobius vermicularis and acute appendicitis. Acta Chir Scand 1985; 151: 705-7.

10. Dahlstrom JE, Macarthur EB. Enterobius vermicularis: a possible cause of symptoms resembling appendicitis. Aust N Z J Surg 1994; 64: 692-4. [CrossRef]

11. Wiebe BM. Appendicitis and Enterobius vermicularis. Scand J Gastroenterol 1991; 26: 336-8. [CrossRef]

12. Budd JS, Armstrong C. Role of Enterobius vermicularis in the aetiology of appendicitis. Br J Surg 1987; 74: 748-9. [CrossRef]

13. Sah SP, Bhadani PP. Enterobius vermicularis causing symptoms of appendicitis in Nepal. Trop Doct 2006; 36: 160-2. [CrossRef]

14. Chamisa I. A clinicopathological review of 324 appendices removed for acute appendicitis in Durban, South Africa: a retrospective analysis. Ann R Coll Surg Engl 2009; 91: 688-92. [CrossRef]

15. Akbulut $\mathrm{S}$, Tas $\mathrm{M}$, Sogutcu $N$, Arikanoglu, Basbug M, Ulku A, et al. Unusual histopathological findings in appendectomy specimens: a retrospective analysis and literature review. World J Gastroenterol 2011; 17: 1961-70. [CrossRef]

16. Rosai J. Rosai and Ackerman's Surgical Pathology. Ninth edition. Edinburgh: Mosby; 2004, p. 2683-712.

17. Dorfman S, Cardozo J, Dorfman D, Del Villar A. The role of parasites in acute appendicitis of pediatric patients. Invest Clin 2003; 44: 337-40.

18. Gupta SC, Gupta AK, Keswani NK, Singh PA, Tripathi AK, Krishna V. Pathology of tropical appendicitis. J Clin Pathol 1989; 42: 1169-72. [CrossRef]

19. Dorfman S, Talbot IC, Torres R, Cardozo J, Sanchez M. Parasitic infestation in acute appendicitis. Ann Trop Med Parasitol 1995; 89: 99-101.

20. Babür C, Kılıç S, Taylan Özkan A, Esen B. Refik Saydam Hıfzıssıhha Merkezi Başkanlığı Parazitoloji Laboratuarında 1995-2000 Yılları Saptanan Bağırsak Parazitlerinin Değerlendirilmesi. T Parazitol Derg 2002; 26: 286-91.

21. Demirel MM, İnceboz T, Yegane S. Çocukluk döneminde gastroenterite neden olan bağırsak parazitlerinin araştırılması. T Parazitol Derg 2001; 24: 367-9.

22. Okyay P, Ertug S, Gultekin B, Onen O, Beser E. Intestinal parasites prevalence and related factors in school children: a western city sample-- Turkey. BMC Public Health 2004; 4: 64. [CrossRef]

23. Saygi G, Ozçelik S, Poyraz O. A survey of intestinal parasites in students an Adult Educational Center in Sivas, Turkey. J Egypt Soc Parasitol 1995; 25: 303-10.

24. Tanyuksel M, Yilmaz H, Ulukanligil M, Araz E, Cicek M, Koru O, et al. Comparison of two methods (microscopy and enzyme-linked immunosorbent assay) for the diagnosis of amebiasis. Exp Parasitol 2005; 110: 322-6. [CrossRef]

25. Tanyuksel, M, Petri WA Jr. Laboratory diagnosis of amebiasis. Clin Microbiol Rev 2003; 16: 713-29. [CrossRef]

26. Still GF. Observations on Oxyuris Vermicularis in Children. Br Med J. 1899; 1: 898-900. [CrossRef] 
27. Gialamas E, Papavramidis T, Michalopoulos N, Karayannopoulou G, Cheva A, Vasilaki $O$, et al. Enterobius vermicularis: a rare cause of appendicitis. T Parazitol Derg 2012; 36: 37-40. [CrossRef]

28. Yildirim S, Nursal TZ, Tarim A, Kayaselcuk F, Noyan T. A rare cause of acute appendicitis: parasitic infection. Scand J Infect Dis 2005; 37: 757-9. [CrossRef]

29. Aydin $O$. Incidental parasitic infestations in surgically removed appendices: a retrospective analysis. Diagn Pathol 2007; 2: 16. [CrossRef]

30. Isik B, Yilmaz M, Karadag N, Kahraman L, Sogutlu G, Yılmaz S, et al. Appendiceal Enterobius vermicularis infestations in adults. Int Surg 2007; 92: 221-5.

31. Nadler S, Cappell MS, Bhatt B, Matano S, Kure K. Appendiceal infection by Entamoeba histolytica and Strongyloides stercoralis presenting like acute appendicitis. Dig Dis Sci 1990; 35: 603-8. [CrossRef]
32. Malik AK, Hanum N, Yip $\mathrm{CH}$. Acute isolated amebic appendicitis. Histopathology 1994; 24: 87-8. [CrossRef]

33. Gotohda N, Itano S, Okada Y, Horiki S, Endo A, Terada N, et al. Acute appendicitis caused by amebiasis. J Gastroenterol 2000; 35: 861-3. [CrossRef]

34. Zardawi IM, Kattampallil JS, Rode JW. Amoebic appendicitis. Med J Aust 2003; 178: 523-4.

35. Ciftci AO, Karnak I, Senocak ME, Kale G, Büyükpamukçu N. Spectrum of complicated intestinal amebiasis through resected specimens: incidence and outcome. J Pediatr Surg 1999; 34: 1369-73. [CrossRef]

36. Sartorelli $A C$, da Silva MG, Rodrigues MA, da Silva RJ. Appendiceal taeniasis presenting like acute appendicitis. Parasitol Res 2005; 97: 171-2. [CrossRef]

37. Guzmán-Valdivia G. Acute amebic appendicitis. World J Surg 2006; 30: 1038-42. [CrossRef] 